\title{
INITIAL GROWTH OF Dipteryx alata PLANTS UNDER WATER DEFICIT ${ }^{1}$
}

\author{
Fabio Santos Matos ${ }^{2 *}$, Igor Alberto Silvestre Freitas ${ }^{3}$, Lidiane Villas Boas Dos Santos ${ }^{3}$, Daniel Guimarães
} Venâncio ${ }^{4}$ and Patrícia Souza da Silveira ${ }^{5}$

\footnotetext{
${ }^{1}$ Received on 28.08.2015 accepted for publication on 31.10.2017.

${ }^{2}$ Universidade Estadual de Goiás, Departamento de Produção Vegetal, Ipameri, Goiás - Brasil. E-mail: <fabio.agronomia@hotmail.com>.

${ }^{3}$ Universidade Estadual de Goiás, Programa de Pós-Graduação em Produção Vegetal, Ipameri, Goiás - Brasil. E-mail: <igor_alberto99@hotmail.com> and <1.villasboass@gmail.com>.

${ }^{4}$ Universidade Estadual de Goiás, Graduado em Agronomia, Ipameri, Goiás - Brasil. E-mail: <daniel_guimaraes14@hotmail.com>.

${ }^{5}$ Universidade Estadual de Goiás, Graduado em Engenharia Florestal, Ipameri, Goiás -Brasil. E-mail: <patyagrovida@yahoo.com.br>.

*Corresponding author.
}

\begin{abstract}
The objective of this study was to analyze the effect of water deficit stress on the growth of Dipteryx alata plants. The experiment was carried out on a bench in full sun at the Goiás State University experimental unit, in Ipameri town, Goiás. Dipteryx alata seeds were collected from native plants in that municipality and sown in four-liter pots containing a mixture of soil, sand and cattle manure at ratio $3: 1: 0.5$, respectively. The experiment was set up following the completely randomized design with five treatments (plants irrigated for 25 days with water volumes corresponding to $0 \%, 25 \%, 50 \%, 75 \%$, and $100 \%$ of daily evapotranspiration) and six replicates. Treatments were applied when the plants were 60 days old, and at 85 days the plants were assessed for the following parameters: plant height, stem diameter, number of leaves, foliar chlorophyll concentration $(a+b)$, total carotenoids, relative water content, transpiration, leaf, stem and root mass ratios, and total biomass. During early development, the Dipteryx alata plants were highly sensitive to water deficit, significantly slowing down vegetative growth. Accordingly, in order to remain alive, the plants drastically reduced transpiration as a result of high stomatal sensitivity.
\end{abstract}

Keywords: Forest seedlings; Water restriction; Forestry.

\section{CRESCIMENTO INICIAL DE PLANTAS DE Dipteryx ALATA SOB DÉFICIT HÍDRICO}

\begin{abstract}
RESUMO-O presente estudo objetivou avaliar o efeito do déficit hídrico no crescimento inicial de plantas de Dipteryx alata. O trabalho foi conduzido em bancada a pleno sol no campo experimental da Universidade Estadual de Goiás, Campus de Ipameri, Goiás. As sementes de Dipteryx alata foram coletadas de planta nativa no município de Ipameri, GO, semeadas em vasos de quatro litros contendo uma mistura de solo, areia e esterco na proporção de 3:1:0,5 respectivamente. O experimento foi montado seguindo o delineamento inteiramente casualizado com cinco tratamentos (Plantas irrigadas com volumes de água correspondentes a $0 \%$ 25\%; 50\%; 75\%; $100 \%$ da evapotranspiração diária durante 25 dias) e seis repetições. Os tratamentos foram impostos quando as mudas possuíam 60 dias de idade e aos 85 dias as mesmas foram submetidas às seguintes avaliações: Altura de planta, diâmetro do caule, número de folhas, concentrações foliares de clorofilas (a+b) e carotenoides totais, teor relativo de água, transpiração, razões de massa foliar, caulinar e radicular e biomassa total. As plantas de Dipteryx alata na fase inicial do desenvolvimento apresentam elevada sensibilidade ao déficit hídrico, inclusive, com significativa redução do crescimento vegetativo, no entanto, para se manterem vivas as plantas reduzem drasticamente a transpiração em função da elevada sensibilidade estomática.
\end{abstract}

Palavras-Chave: Mudas florestais, restrição hídrica, silvicultura 


\section{INTRODUCTION}

The competitiveness in the Brazilian forestry sector, arising from ideal climate conditions and high technology application, places the country in an outstanding position in the world scenario (Ferreira et al., 2012). Brazil is the world's third greatest timber producer and the fourth producer of paper cellulose (CEPEA, 2014). Planted forests account for $1.2 \%$ of GDP, $24 \%$ of the agriculture and livestock sector GDP, employ 4.5 million people, and take only $1 \%$ of Brazil's productive land (Amazônia, 2015). The Brazilian forest vegetation cover is approximately 463 million hectares, $98.5 \%$ of which is estimated to consist of native forests located mostly in the country's North region. The remainder (1.5\%) corresponds to planted forests. The predominant tree species in Brazilian planted forests are eucalyptus and pine (ABIMCI, 2014). Notwithstanding its high potential in the forestry sector, the country can further increase that production and transfer wealth to other economy segments through the expansion of the agricultural frontier.

Such expansion depends on the tolerance of species to the abiotic stresses prevailing in several regions of the country, such as the Northeast. Climate changes have extended water deficit periods in many parts of the world, and abiotic stress is the leading cause of low crop productivity worldwide, reducing by over $50 \%$ the average yields of most cultivated plants. In forests, water deficit is the most limiting factor to agriculture, as it reduces plant growth and increases their mortality (Zang et al., 2014). Working with forest species that tolerate drought may expand commercial exploitation of planted forests in areas considered inept due to low water availability.

As water resources become increasingly scarce, the development of drought-tolerating plants figures as a priority in obtaining high productivity. And drought tolerance is a result of various characteristics (anatomic, morphologic, physiologic, and molecular ones), which are expressed in different and concurrent ways depending on the water deficit severity and rate. The cultivation of species tolerant to water deficit will ensure income to producers from regions with semi-arid climate (Matos et al., 2014). This way, the exploitation of northeastern areas with planted forests may increase the Brazilian regional agriculture GDP. However, it is important to explore forest species other than traditional ones (eucalyptus and pine) in order to render the sector less vulnerable to weather and environmental conditions.

Dipteryx alata stands out among promising forest species for field cultivation in different regions of Brazil. It is a country species easily adaptable to diverse types of soil and figures among the ten most promising native plants from the Brazilian cerrado for commercial cropping as planted forest, given its high germination rate, good seedling establishment, nitrogen fixation, timber yield, as well as medicinal, ornamental and feeding potential (Pacheco, 2008; Soares et al., 2008). The Dipteryx alata almond presents protein content superior to that of leguminous plants, being therefore recommended for feeding (Togashi et al., 1994).

According to Mosquetta et al. (2011), the Dipteryx alata almond is a low-cost bioadsorbent for the extraction of nickel (nickel enhances ethanol corrosive properties and increases soil, air and water pollution) with hydrated ethyl alcohol. The plant is original from Brazil, grows throughout the entire cerrado biome (Ratter et al., 2003), and yields high quality timber and fruits of commercial value (Cruz et al., 2011; Magalhães, 2014). The tree can grow up to $25 \mathrm{~m}$ tall and reach $70-\mathrm{cm}$ diameter at chest height when mature (Carvalho, 2010).

Multiple-application forest species like Dipteryx alata may represent an important commercial alternative, as they allow for complementary income from the harvesting and processing of their fruits (Leite et al., 2010). Brazil has a number of native forest species with economic potential, however the lack of scientific information is a major barrier to commercial cropping. Existing information regarding the development of Dipteryx alata under water deficit stress is insufficient to ensure economic pay-off in the field. The development of research to evaluate the species physiologic performance under drought conditions is required to provide basic understanding of the plant development in the field. Aiming to provide part of the lacking knowledge on the physiology of Dipteryx alata plants, this study was designed to evaluate the effect of water deficit stress on the early growth of Dipteryx alata plants.

\section{MATERIALAND METHODS}

The research was carried out on a bench in full sun at the Goiás State University experimental unit in Ipameri Campus (17\%43'19"S, 48 09'35"W, Alt. 773m), Ipameri, Goiás. According to Köppen classification

Revista Árvore. 2018;42(1):e420103

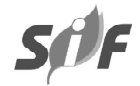


the region has tropical climate (Aw) with dry winter and rainy summer. Dipteryx alata seeds were collected from native plants in Ipameri municipality and sown in four-liter pots containing a mixture of soil, silt and cattle manure at ratio $3: 1: 0.5$, respectively. Chemical analysis of the mixture showed the following values: pH $6.4 ; 19 \mathrm{~g} \mathrm{dm}-3$ of NOM; $2.4 \mathrm{mg} \mathrm{dm}-3$ of P, 109 cmolc dm-3 of K, 1.5 cmolc dm-3 of $\mathrm{H}+\mathrm{Al}, 3.2$ cmolc dm-3 of Ca, $1.6 \mathrm{cmolc} \mathrm{dm}-3$ of Mg, $27.7 \mathrm{mg} \mathrm{dm}-3$ of Zn, $77.20 \%$ of BS, and 6.58 of CEC. After analysis of the mixture composition based on $\mathrm{pH}$, availability of nutrients and organic matter, decision was made to not apply lime or carry out fertilization.

The experiment was set up according to the completely randomized design with five treatments (plants irrigated for 25 days with water volumes corresponding to $0 \% ; 25 \%$; $50 \% ; 75 \% ; 100 \%$ of daily evapotranspiration) and six replicates. The treatments were applied when the seedlings were 60 days old. Since the crop coefficient $(\mathrm{kc})$ for Dipteryx alata has yet to be determined for the Ipameri region (GO), a $\mathrm{kc}$ of 1.00 was applied in accordance with the FAO-56 estimate (Allen et al., 1998) for a group of crops in the initial growth stage. The volume of water provided was estimated based on the reference evapotranspiration and crop coefficient. Crop evapotranspiration was determined using the equation:

$$
\mathrm{ETc}=\mathrm{ETo} \mathrm{x} \mathrm{kc}
$$

Where:

$$
\begin{aligned}
& \mathrm{ETc}=\text { crop evapotranspiration } \\
& \mathrm{kc}=\text { crop coefficient } \\
& \mathrm{ETo}=\text { Reference evapotranspiration }
\end{aligned}
$$

Daily ETo was calculated by the FAO PenmanMonteith method (Smith et al., 1991) using daily data on minimum and maximum temperature, relative humidity, solar radiation and wind speed obtained from the INMET Weather Station located in the municipality of Ipameri, GO.

At 85 days after emergence the plants were assessed for: plant height, stem diameter, number of leaves, foliar chlorophyll concentrations $(\mathrm{a}+\mathrm{b})$ and total carotenoids, relative water content, transpiration, leaf, stem and root mass ratios, and total biomass.

\subsection{Growth variables}

The number of leaves, plant height and stem diameter were measured by counting, using a graduated ruler and a digital pachymeter. For destructive analyses, the leaves, roots and stems were extracted and ovendried at $72^{\circ} \mathrm{C}$ to obtain constant dry mass. Then, they were weighed separately. The dry mass data allowed for the calculation of the leaf mass ratio (LMR), root mass ratio (RMR), stem mass ratio (SMR), and total biomass.

\subsection{Relative water content and transpiration}

The relative water content was determined by extracting ten 12-mm diameter foliar discs, which were weighed and saturated for four hours in Petri dishes with distilled water. Next, the discs were weighed again and dried at $70^{\circ} \mathrm{C}$ for 72 hours in order to obtain the dry weight in grams. Total daily plant transpiration was determined by the difference in weight of the pots. First, each pot was placed inside a plastic bag attached to the stem of the plant with a rubber band, leaving only the aerial parts (stem and leaves) exposed. Next, the pot (and bag) was weighed at 12pm (weight 1) and then again 24 hours later (weight 2 ). Total transpiration was estimated based on the difference between weights 1 and 2.

\subsection{Photosynthetic pigments}

In order to determine the total concentrations of chlorophylls and carotenoids $(\mathrm{Cl} \mathrm{a}+\mathrm{b})$ two $1.0-\mathrm{cm}$ foliar discs were extracted (third pair of fully expanded leaves) and placed in dishes containing dimethyl sulfoxide (DMSO). Subsequently, extraction was carried out in $65^{\circ} \mathrm{C}$ water bath for three hours when the discs were completely discolored. Aliquots were extracted for spectrophotometric analysis at 490, 646 and $663 \mathrm{~nm}$. Chlorophyll a and chlorophyll b contents were determined through the equation proposed by Wellburn (1994).

\subsection{Statistic procedures}

The experiment followed the completely randomized design, with five treatments and six replicates. The data were submitted to regression analysis using software R (R Core Team, 2015).

\section{RESULTS}

Analysis of the results showed little variation among treatments for foliar total carotenoids and root mass ratio. These variables did not present significant difference by $\mathrm{F}$ test, and the data did not conform to any significant regression model at 5\% probability (results not shown). 
Foliar concentration of chlorophylls $(a+b)$, total transpiration and relative water content varied significantly among treatments (Figure 1). These variables presented values directly proportional to water availability and, consequently, they fit into the crescent linear regression model.

Growth variables - plant height, number of leaves, stem diameter and biomass - varied significantly among treatments (Figure 2). Vegetative growth was directly proportional to the water volume applied, and so variables showed crescent linear regression.
Stem and leaf mass ratios also varied significantly among treatments. The values for both variables increased according to the applied water volume (Figure 3 ).

\section{DISCUSSION}

Uncertainties related to the consequences of climate changes have focused research studies on expanding the knowledge of the development of species under diverse environmental conditions. Drought tolerance may contribute to the expansion of the agricultural frontiers and commercial exploitation of Dipteryx alata
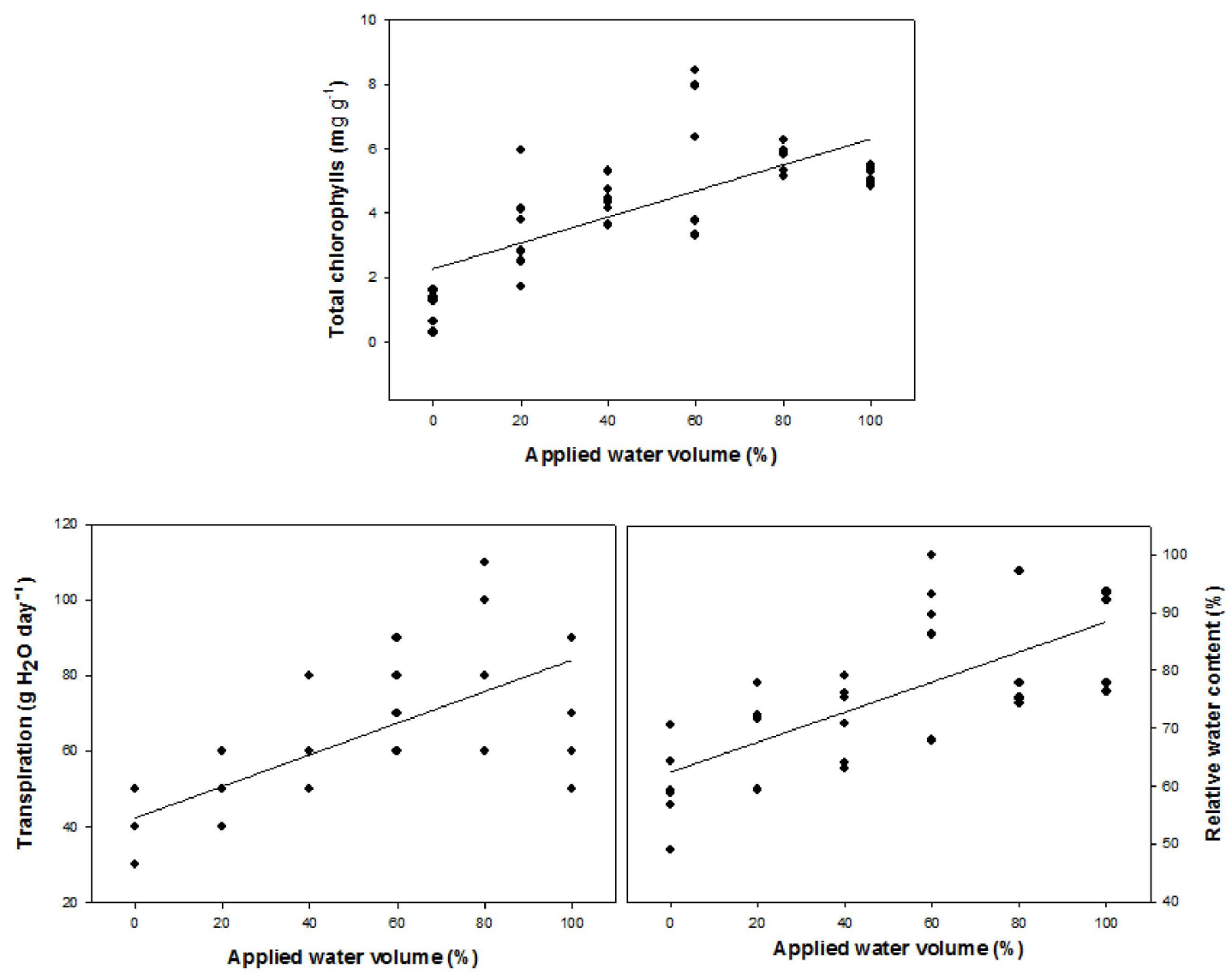

Figure 1 - Regression equations for total chlorophyll $\left(\hat{Y}=2.27+0.04 x, R^{2}=0.91^{*}\right)$; total transpiration $\left(\hat{Y}=42.34+0.42 x, R^{2}=0.93^{*}\right)$ and relative water content $\left(\hat{Y}=62.43+0.26 x, \mathrm{R}^{2}=0.98^{*}\right)$ in Dipteryx alata seedlings irrigated with different water volumes corresponding to daily evapotranspiration (\%). *Significant at $5 \%$ probability.

Figura 1 - Equações de regressão para clorofila total $Y=2,27+0,04 x, R^{2}=0,91^{*}$; transpiração total $Y=42,34+0,42 x, R^{2}=0,93^{*}$ e teor relativo de água $Y=62,43+0,26 x, R^{2}=0,98^{*}$ de mudas de Dipteryx alata irrigadas com diferentes volumes de água referentes a evapotranspiração diária (\%). " Significativo ao nível de $5 \%$ de probabilidade.

Revista Árvore. 2018;42(1):e420103 

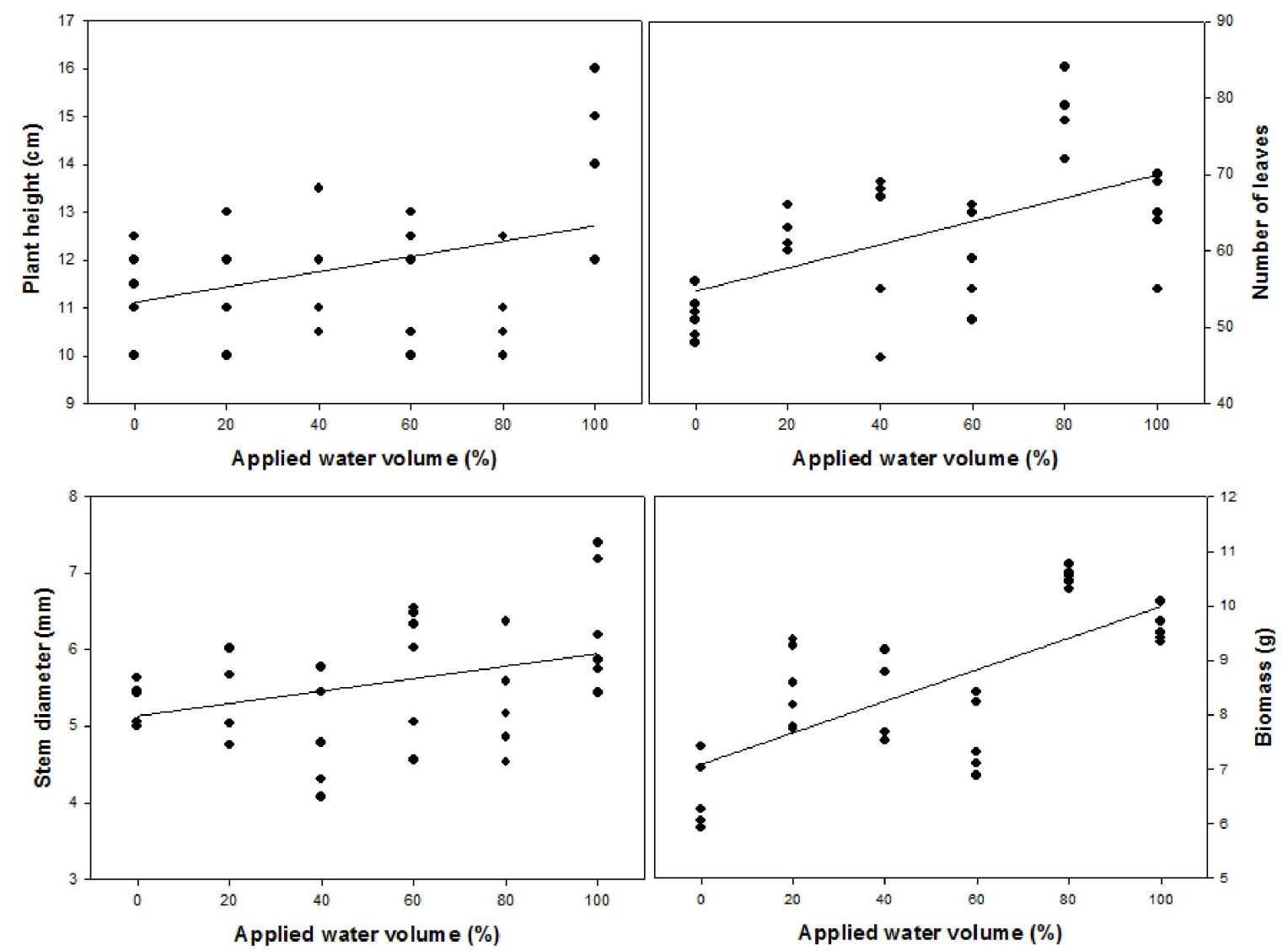

Figure 2 - Regression equations for plant height $\left(\hat{Y}=11.12+0.016 x, R^{2}=0.98^{*}\right)$, number of leaves $\left(\hat{Y}=54.73+0.15 x, R^{2}=0.98^{*}\right)$, stem diameter $\left(\mathrm{Y}=5.1350+0.0081 \mathrm{x}, \mathrm{R}^{2}=0.98^{*}\right)$ and biomass $\left(\mathrm{Y}=7.08+0.029 \mathrm{x}, \mathrm{R}^{2}=0.98^{*}\right)$ of Dipteryx alata plants irrigated with different water volumes corresponding to daily evapotranspiration (\%). "Significant at $5 \%$ probability.

Figura 2 - Equações de regressão para altura de planta $Y=11,12+0,016 x, R^{2}=0,98^{*}$, número de folha $Y=54,73+0,15 x$, $R^{2}=0,98^{*}$, diametro do caule $Y=5,1350+0,0081 x, R^{2}=0,98^{*}$ e biomassa $Y=7,08+0,029 x, R^{2}=0,98^{*}$ de mudas de Dipteryx alata irrigadas com diferentes volumes de água referentes a evapotranspiração diária (\%). *Significativo ao nivel de $5 \%$ de probabilidade.

in regions with semi-arid climate. Resistance to abiotic stress is key to the survival and establishment of forest species in tropical ecosystems (Worbes et al., 2013).

It is important to note that regardless of the drought level rate, the plant Dipteryx alata survived. The significant reduction in transpiration and relative water content indicates a change in the hydration status of Dipteryx alata plants. The drastic reduction in the relative water content indicates that even under high stomatal control, the plant was unable to maintain high tissue hydration (as is the case with succulent stem species).
The high stomatal sensitivity, typical of isohydric plants, may have affected the carbon assimilation rate and, consequently, the vegetative growth of treated plants. The significant decrease in height, number of leaves, stem diameter and biomass is a result of carbon assimilation reduction caused by $\mathrm{CO} 2$ limited diffusion from the atmosphere into the plant. According to Taiz and Zeiger, (2013) water loss gradient is approximately 50 times higher than the $\mathrm{CO} 2$ inflow gradient, thus limited when the plant water loss limits the inflow of more CO2. The decrease in growth and the increase in mortality are common in forest species subjected 

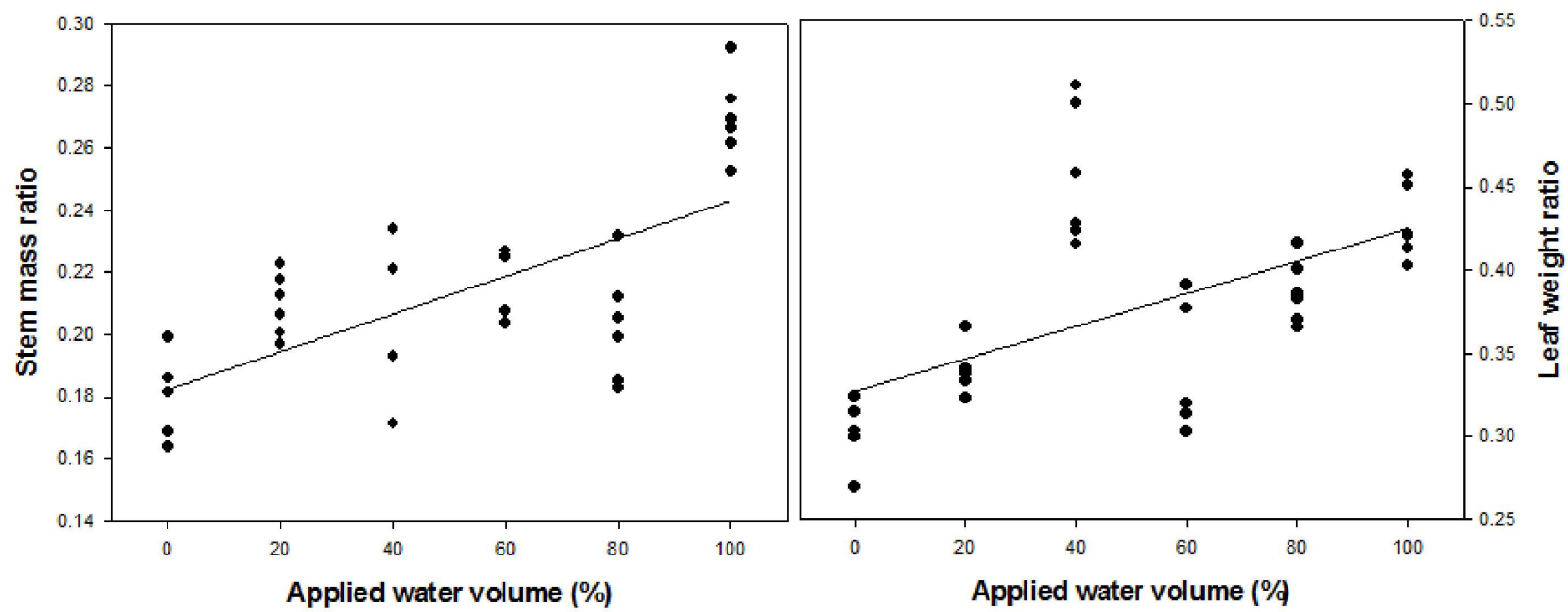

Figure 3 - Regression equations for stem mass ratio $\left(\hat{Y=} 0.18+0.0006 x, R^{2}=0.98^{*}\right)$ and leaf mass ratio $(\hat{Y} Y=0.3272+0.0010 x$, $\mathrm{R}^{2}=0.98^{*}$ ) of Dipteryx alata seedlings irrigated with different water volumes corresponding to daily evapotranspiration (\%). *Significant at $5 \%$ probability.

Figura 3 - Equações de regressão para razão de massa caulinar $Y=0,18+0,0006 x, R^{2}=0,98^{*}$ e razão de massa foliar $Y=0,3272+0,0010 x, R^{2}=0,98^{*}$ de mudas de Dipteryx alata irrigadas com diferentes volumes de água referentes a evapotranspiração diária (\%). "Significativo ao nível de $5 \%$ de probabilidade.

to low water supply (Allen et al., 2010). The results corroborate those found by Hommel et al. (2014), who studied stomatal and mesophilic conductance in forest species and concluded that stomate closing in response to water deficit affects water use efficiency and decreases the photosynthesizing rate. Transpiration and biomass accumulation in Eucalyptus urogradis and other woody plants significantly decrease under water deficit (Pereira et al., 2006; Albuquerque et al., 2013).

The reduction in foliar chlorophyll concentration may be associated to morphophysiological adjustment of the species in order to decrease the absorption of light energy, produce less photochemical energy and generate less reactive species. It is a photoprotection mechanism of the species, since under water deficit stress the formation of free radicals that damage membranes and proteins is common (Matos et al., 2009).

In addition, it is noted that there is a strong relationship between the availability of nitrogen and activity of the reductase enzyme nitrate and this is extremely sensitive to water stress (Reis et al., 2007), thus less nitrogen may have been made available for the synthesis of pigments. Such alterations may be related to the phenotype plasticity of Dipteryx alata, since Brazilian cerrado species are naturally and constantly subjected to diverse combinations of climate and soil, and possibly some evolutionary need might have favored the species survival through morphophysiological adjustments. According to Palhares et al. (2010), the development of certain species under limiting conditions was due to evolutionary pressure that caused an important selection of plants in the Brazilian cerrado.

The results indicate that at the early development stage the vegetative growth of Dipteryx alata plants is highly decreased under water deficit stress. However, further studies with adult plants in the field are required to determine potential tolerance to drought, since recent research has found that drought tolerance may be associated to low tree growth rates (Rose et al., 2009; Taeger et al., 2013).

\section{CONCLUSIONS}

At early development stage Dipteryx alata plants showed high sensitivity to water deficit with significant reduction in vegetative growth. However, in order to remain alive, they drastically decreased transpiration as a result of high stomatal sensitivity.

Revista Árvore. 2018;42(1):e420103 


\section{ACKNOWLEDGEMENTS}

To Goiás State University (UEG), Coordination for the Improvement of Higher Education (CAPES) and Foundation for Support to Goiás State Research (FAPEG) for the project financing: AUXPE 2370/2014.

\section{REFERENCES}

Albuquerque MPFD, Moraes FKC, Santos RIN, Castro GLS, Ramos EMLS, Pinheiro HA. Ecofisiologia de plantas jovens de mogno-africano submetidas a déficit hídrico e reidratação. Pesquisa Agropecuária Brasileira. 2013;48:9-16.

Amazônia. Accessed on: 4 May, 2015. Available at: www.amazônia.org.br.

Associação Brasileira da Indústria de Madeira Processada Mecanicamente - ABIMCI. Acessed on: 4 May, 2015. Available at: www.abimci.com.br

Allen C, Macalady A, Chenchouni H. A global overview of drought and heat-induced tree mortality reveals emerging climate change risks for forests. Forest Ecology and Management. 2010;259(4):660-84

Allen RG, Pereira LS, Raes D, Smith M. Crop evapotranspiration: guidelines for computing crop water requirements. Rome: FAO; 1998. 300p. (FAO. Irrigation and Dranaige Paper, 56)

Carvalho PER. Espécies florestais brasileiras: recomendações silviculturais, potencialidades e uso da madeira. Brasília, DF: Embrapa Informação Tecnológica; 2010. 644p.

Centro de estudos avançados em economia aplicada - CEPEA. Acessado on: 27 Apr. 2015. Available at: http://cepea.esalq.usp.br/pib.

Cruz KS, Silva MA, Freitas O, Neves VA. Partial characterization of proteins from baru (Dipteryx alata Vog) seeds. Journal of the Science of Food and Agriculture. 2011;91(11):2006-12.

Ferreira SM, Petrauski C, Marques GM, Silva ML, Cordeiro AS, Soares NS. Competitividade do Brasil no mercado internacional de madeira serrada. Cerne. 2012;18(1):99-104.

Hommel R, Siegwolf R, Saurer M, Farquhar GD, Kayler Z, Ferrio JP. et al. Drought response of mesophyll conductance in forest understory species - impacts on water-use efficiency and interactions with leaf water movement.

Physiologia Plantarum. 2014;152(1):98-114.

Leite EM, Santos RV, Souto PC, Vital AFM, Araújo JL. Crescimento inicial de espécies arbóreas em solo degradado do semiárido tratado com corretivos. Revista Verde de Agroecologia e Desenvolvimento Sustentável. 2010;5(3):179-87.

Magalhães RM. A cadeia produtiva da amêndoa do baru (Dipteryx alata Vog.) no cerrado: uma análise da sustentabilidade da sua exploração. Ciência Florestal. 2014;24( 3):665-76.

Matos FS, Moreira CV, Missio RF, Dias LAS. Caracterização fisiológica de mudas de Jatropha curcas L. produzidas em diferentes níveis de irradiância. Revista Colombiana de Ciências Hortícolas. 2009;3(1):126-34.

Matos FS, Torres Junior HD, Rosa VR, Santos PGF, Borges LFO, Ribeiro RP. et al. Estratégia morfofisiológica de tolerância ao water deficit de mudas de pinhão manso. Magistra. 2014;26(1):19-27.

Mosquetta R, Ribeiro GC, Munoz RAA, Coelho NMM. Uso de Amêndoas de Dypterix alata para remoção de Ni(II) em etanol combustível. Química Nova. 2011;34(6):923-7.

Pacheco AR. Adubação de mudas de baru (Dipteryx alata Vog.), em viveiro [tese] Goiânia: Escola de Agronomia e Engenharia de Alimentos, Universidade Federal de Goiás; 2008.

Palhares D, Franco AC, Zaidan LBP. Respostas fotossintéticas de plantas de cerrado nas estações seca e chuvosa. Revista Brasileira Biociências. 2010;8(2):213-20.

Pereira LS, Raes D, Perrier A, Alves I, Walter I, Elliott RA. Recommendation on standardized surface resistance for hourly calculation of reference ETo by the FAO 56 Penman-Monteith method. Agricultural Water Management. 2006;81(1):1-22.

R Core Team. R: A language and environment for statistical computing. Vienna: R Foundation for Statistical Computing. [accessed on: 19 Aug. 2015]. Avaiable at: http://www,R-project,org/. 
Ratter JA, Bridgewater S, Ribeiro JF. Analysis of the floristic composition of the Brazilian cerrado vegetation III: Comparison of the woody vegetation of 376 areas. Edinburgh Journal of Botany. 2003;60(1):57-109.

Reis AR, Furlani Júnior E, Haga KI. Atividade da redutase do nitrato em folhas de cafeeiro em função da adubação nitrogenada. Acta Scientiarum Agronomy. 2007;29:269-76.

Rose L, Leuschner C, Kocknemann B, Buschmann H. Are marginal beech (Fagus sylvatica L.) provenances a source for drought tolerant ecotypes? European Jounal of Florest Research. 2009;128(4):335-43.

Smith M. Report on the expert consultation on revision of FAO methodologies for crop water requiremebts. Rome: FAO; 1991.

Soares TN, Chaves JL, Telles MPC, Diniz-Filho JAF, Resende LV. Distribuição espacial da variabilidade genética intrapopulacional de Dipteryx alata. Pesquisa Agropecuária Brasileira. 2008;43(9):1151-8.

Taeger S, Zang C, Liesebach M, Schneck V, Menzel A. Impact of climate and drought events on the growth of Scots pine (Pinus sylvestris L.) provenances. Forest Ecology and Management. 2013;307:30-42.

Taiz L, Zeiger E. Fisiologia vegetal. $5^{\text {a }}$.ed. Porto Alegre: Artmed; 2013.918p.

Togashi M, Sgarbieri VC. Caracterização química parcial do fruto do baru (Dipteryx alata, Vog.). Ciência e Tecnologia de Alimentos. 1994;14(1):8595.

Zang C, Meier CH, Dittmar C, Rotche A, Menzel A. Patterns of drought tolerance in major European temperature forest trees: Climatic drivers and levels of variability. Global Change Biology. 2014;20(12):3767-79.

Wellburn AR. The spectral determination of chlorophylls a and b, as well as total carotenoids, using various solvents with spectrophotometers of different resolution. Journal of Plant Physiology. 1994;144(3):307-13.

Worbes M, Blanchart S, Fichtler E. Relations between water balance, wood traits and phonological behavior of tree species from a tropical dry forest in Costa Rica - a multifactorial study. Tree Physiology. 2013;33(5):527-36

Revista Árvore. 2018;42(1):e420103 